\title{
Perception of Fogera Cattle Farmers on Climate Change and Variability in Awi Zone, Ethiopia
}

\author{
Michael Abera ${ }^{1,2}{ }^{*}$, Yesihak Yusuf Mummed ${ }^{3}$, Mitiku Eshetu ${ }^{3}$, Fabio Pilla4, Zewdu Wondifraw ${ }^{1}$ \\ ${ }^{1}$ Department of Animal Sciences, Debre Markos University, Debre Markos, Ethiopia \\ ${ }^{2}$ Africa Center of Excellence for Climate Smart Agriculture and Biodiversity Conservation, Haramaya University, Dire Dawa, \\ Ethiopia \\ ${ }^{3}$ School of Animal and Range Sciences, Haramaya University, Dire Dawa, Ethiopia \\ ${ }^{4}$ University of Molise, Campobasso, Italy \\ Email: ^michaelabera76@gmail.com, mitikuguya@yahoo.com, zewduwondifraw@gmail.com, pilla@unimol.it, \\ yesihakyus@gmail.com
}

How to cite this paper: Abera, M., Mummed, Y.Y., Eshetu, M., Pilla, F. and Wondifraw, Z. (2020) Perception of Fogera Cattle Farmers on Climate Change and Variability in Awi Zone, Ethiopia. Open Journal of Animal Sciences, 10, 792-815. https://doi.org/10.4236/ojas.2020.104052

Received: September 28, 2020

Accepted: October 27, 2020

Published: October 30, 2020

Copyright $\odot 2020$ by author(s) and Scientific Research Publishing Inc. This work is licensed under the Creative Commons Attribution International License (CC BY 4.0).

http://creativecommons.org/licenses/by/4.0/

\begin{abstract}
This study aimed at assessing perception of Fogera cattle farmers on climate change and variability in selected districts of Awi zone. The zone was classified as lowland $(<1500)$, midland (1500 - 2500), and highland (>2500 m.a.s.l) based on altitudinal variation from which a total of three districts one per cluster were selected through random sampling. 150 households were selected through systematic random sampling targeting Fogera cattle owners for primary data collection. Over 36 years (from 1983-2019) of meteorological data were taken from the National Meteorological Agency. Meteorological data result confirmed that climate was changing across all the agro-ecological zones. Both the mean annual maximum and minimum temperature was considerably increasing for all agro-ecological zones whereas the mean annual rainfall was decreasing which is consistent with the farmers' perception. Meteorological data result also showed that the short rainy and dry season rainfall indicated high interannual variability at all agro-ecological zones. Survey result revealed that $97.13 \%$ of the farmers recognized climate change and variability impact in all agro-ecological zones. About $80.91 \%$ of Fogera cattle farmers reported the incidence of negative impacts of climate change and variability on cattle. Chi-square test values of survey results show that in all agro-ecological zones frequency of drought, duration of dry spell, wind, and floods were ever-increasing ( $\mathrm{p}<0.001$ ). Moreover, about $84.48 \%, 65.3 \%$, and $60.47 \%$ of farmers owning Fogera cattle in the lowland, midland, and highland, respectively perceived the prevalence of increasing $(\mathrm{p}<0.001)$ cattle mortality. In response to climate change and variability, farmers were reducing number of livestock, diversification of livestock species, and replacing Fogera cattle with small ruminants as adaptation strategies. Thus, regular
\end{abstract}


prediction of climate change and variability and designing pertinent response strategies is essential to reduce the adverse impacts of climate change for enhancing resilience capacity of the Fogera cattle farmers in the study areas.

\section{Keywords}

Climate Change and Variability, Fogera Cattle Farmers, Perceptions

\section{Introduction}

Livestock is an essential component of nearly all farming systems in Ethiopia and provides draught power, milk, meat, manure, hides, skins, and other products [1]. Currently, the population of livestock found in Ethiopia is estimated to be 60.39 million cattle, 31.30 million sheep, and 32.74 million goats [2]. Moreover, Ethiopia has a diversified climate ranging from the semi-arid desert type in the lowlands to tropical humid and sub-humid in the highland area [3]. The size and diversity of major agro-ecological zones render it suitable for the support of large numbers and classes of livestock [1]. However, many previous studies [4] [5] showed that the country has suffered from climatic variability and extremes. Climate-related hazards in Ethiopia include drought, floods, heavy rains, strong winds, frost, heat waves, and lightning [4]. The consequence of the long-term climate-related to changes in precipitation patterns, rainfall variability, and temperature has increased the frequency of droughts and floods [4] [6]. According to [7] and [8], climate change influences are more severely felt by poor people who rely heavily on the natural resource base for their livelihoods. Climate models show warming in all four seasons over Ethiopia, which may result in more frequent heat waves [9]. Climate change affects livestock production through competition for natural resources, quantity and quality of feeds, livestock diseases, heat stress, and biodiversity loss while the demand for livestock products is expected to increase by $100 \%$ by mid of the $21^{\text {st }}$ century [10]. Cattle are generally the livestock species most susceptible to water and nutritional stresses engendered by climate change and variability, because they are strongly dependent on herbaceous pasture and frequent access to drinking water, which in turn are highly sensitive to variation in precipitation in dry Savannas [11]. Different studies have been conducted in Ethiopia so far [12] [13] [14] [15] but most of them were emphasized on crop production. Thus, little attention was given to cattle farmers. For instance, [16] reported that cattle population size has decreased by $19.8 \%$ from 2008 to 2017 . Another study conducted in Borana area showed that recurrent droughts (89\%) and associated livestock losses (72\%) have increased from 1976 and 1984 to 2008 and 2016 while trends in rainfall (92.1\%), milk production (93\%), and milk and meat consumptions (90.1\%) were declining [17]. Little is known about the perceptions of farmers on northern part of Ethiopia who rear Fogera cattle on climate change and variability. Currently, climate change and variability is affecting world population especially low-income 
countries whose economic activities are mainly dependent on Agriculture. In this regard, the study area is not exceptional. Moreover, the linkage between the perception of Fogera cattle farmers and meteorological data to assess climate change and variability is scarce in the literature. Thus, assessing and understanding the current status of the perceptions of farmers on climate change and variability has paramount importance in designing pertinent management interventions. Therefore, the overall objective of this study was to assess the perceptions of Fogera cattle farmer's on climate change and variability in three selected districts of Awi Zone.

\section{Materials and Methods}

\subsection{Description of the Study Area}

The study was conducted in the three districts (Guangua, Dangila, and Banja) of Awi Zone, Amhara National Regional State of Ethiopia. The Zone has a total of nine districts of which three (3) of them are town administrations. It is $445 \mathrm{~km}$ far from Addis Ababa and $113 \mathrm{~km}$ from the Regional capital city, Bahir Dar. The farming system practiced in the study area is a mixed crop-livestock production system. The area consists of different livestock composition. According to [18], the study site had 1.1 million cattle, 347,299 Sheep, 177,948 goats, and 66,834 horse, 85,488 donkey, 17,138 mules, 873,008 poultry, and 97,518 beehives while the dominant crops grown in the areas were maize, finger millet, wheat, potato, teff, and nug. According to [4], the area has three defined seasons; dry season (October to January), short rainy season (February to May), and the long rainy season (June to September). The three districts (Guangua, Dangila, and Banja) are selected based on their altitudinal variation as lowland $(<1500)$, midland (1500 - 2500), and highland (>2500 m.a.s.l), respectively. The descriptions of the districts are as follows:

\subsubsection{Guangua}

Is located at $35^{\circ} 50^{\prime} 0^{\prime \prime} \mathrm{E}$ to $37^{\circ} 30^{\prime} 0^{\prime \prime} \mathrm{E}$, longitude and $10^{\circ} 20^{\prime} 0^{\prime \prime} \mathrm{N}$ to $11^{\circ} 10^{\prime} 0^{\prime \prime} \mathrm{N}$ latitude, and 1583 m.a.s.l. and far $502 \mathrm{~km}$ northwest of Addis Ababa. The administrative center of this district is Chagni. The monthly mean minimum and maximum temperature is $13.37^{\circ} \mathrm{C}$, and $28.21^{\circ} \mathrm{C}$, respectively. The mean annual rainfall is $1130 \mathrm{~mm}$. The area possesses extensive grassland coverage and perennial river flows, which is suitable for livestock grazing. The major feed resources for livestock in the study area comprise grasses, shrubs, and tree leaves [19]. Herbaceous and woody plants are the major vegetation types of this district. Among the herbaceous species, grasses accounted for $64.3 \%$ of the total herbaceous species with $57 \%$ of the grass species being highly desirable (palatable) Cynodon dactylon, Digitaria ternata, Digitaria velutina, Brachiaria dictyoneura, Commelina benghalensis, and Panicum maximum were the most palatable grass species [20].

\subsubsection{Dangila}

It is located between $36^{\circ} 35^{\prime} 30^{\prime \prime} \mathrm{E}$ to $37^{\circ} 0^{\prime} 30^{\prime \prime} \mathrm{E}$ longitude and $11^{\circ} 05^{\prime} 30^{\prime \prime} \mathrm{N}$ to 
$11^{\circ} 25^{\prime} 30^{\prime \prime} \mathrm{N}$ latitude at an altitude ranging from 1353-2454 m.a.s.l. Most of the landscape of the area is described as a flat surface with a small portion undulating [21]. The monthly mean minimum and maximum temperature is $10.75^{\circ} \mathrm{C}$, and $25.95^{\circ} \mathrm{C}$, respectively. The mean annual rainfall is $1434 \mathrm{~mm}$. Most of the landscape of the district is described as being a flat surface with a small undulating portion. The production system is characterized by mixed farming in which crop and livestock productions are running side by side [22]. The vegetation of the study area is mostly plantation forest of Eucalyptus, and natural tree species Cordia Africana (Wanza), different Acacia species, and Missana are found in the district [23]. A variety of crops, such as annual and perennial crops, grow under rain-fed and irrigation systems. Most of the cereal crops grown in the area are maize, teff, wheat, barley, and finger millet. Besides cereal crops, a variety of vegetables (e.g., onion, tomato, pepper, and cabbage), cash crops (e.g., chat and coffee), and fruit crops (e.g., papaya and banana) are also grown [18].

\subsubsection{Banja Shekudad}

It is located between $36^{\circ} 39^{\prime} 09^{\prime \prime}$ to $36^{\circ} 48^{\prime} 25^{\prime \prime} \mathrm{E}$ longitude and $10^{\circ} 57^{\prime} 17^{\prime \prime}$ to $11^{\circ} 03^{\prime} 05^{\prime \prime} \mathrm{N}$ latitude with an elevation 2560 m.a.s.l. It is situated $122 \mathrm{~km}$ far from the regional city Bahir Dar to south, and $447 \mathrm{~km}$ north to Addis Ababa [24]. The administrative center of this district is Injibara, which is situated in a predominantly mountainous location. The hills and valleys receive high amounts of rain, especially in the rainy season. This high rainfall permits farmers to grow multiple crops in a year [18]. The monthly mean minimum and maximum temperature of the area was $9.12^{\circ} \mathrm{C}$ and $24.65^{\circ} \mathrm{C}$, respectively. The mean annual rainfall was $1602 \mathrm{~mm}$ with the main wet season from June to September. The vegetation type was dominated by Albizia gummifera, Croton macrostachyus, Prunus Africana, and Apodytes dimidiate [24] (Figure 1).

\subsection{Methods of Data Collection}

The relevant data for this study were collected from both primary and secondary sources. The primary source was cross-sectional survey collected from households. The primary data majorly includes socioeconomic characteristics, demography, and farmers' perceptions of climate change and variability. To collect primary data from respondents' survey questionnaires, focus group discussions, and field observations were employed. Three focus group discussions were conducted, one per district, each comprising ten persons. The questionnaires were focused on five themes: 1) Socioeconomic characteristics; 2) Farmers' perception of climate change and variability; 3) Farmers' perception of rainfall patterns; 4) Farmers' perception of temperature trends; 5) Farmers' perception of climate change and variability over the last 30 years and their strategy to cope up with the change. Constraints of Fogera cattle production related to feed resources, water sources, and the prevalence of major diseases in the area were collected. The trend in feed availability, water availability, and occurrence of disease were collected over the last 30 years from Fogera cattle farmers. Questionnaires were 


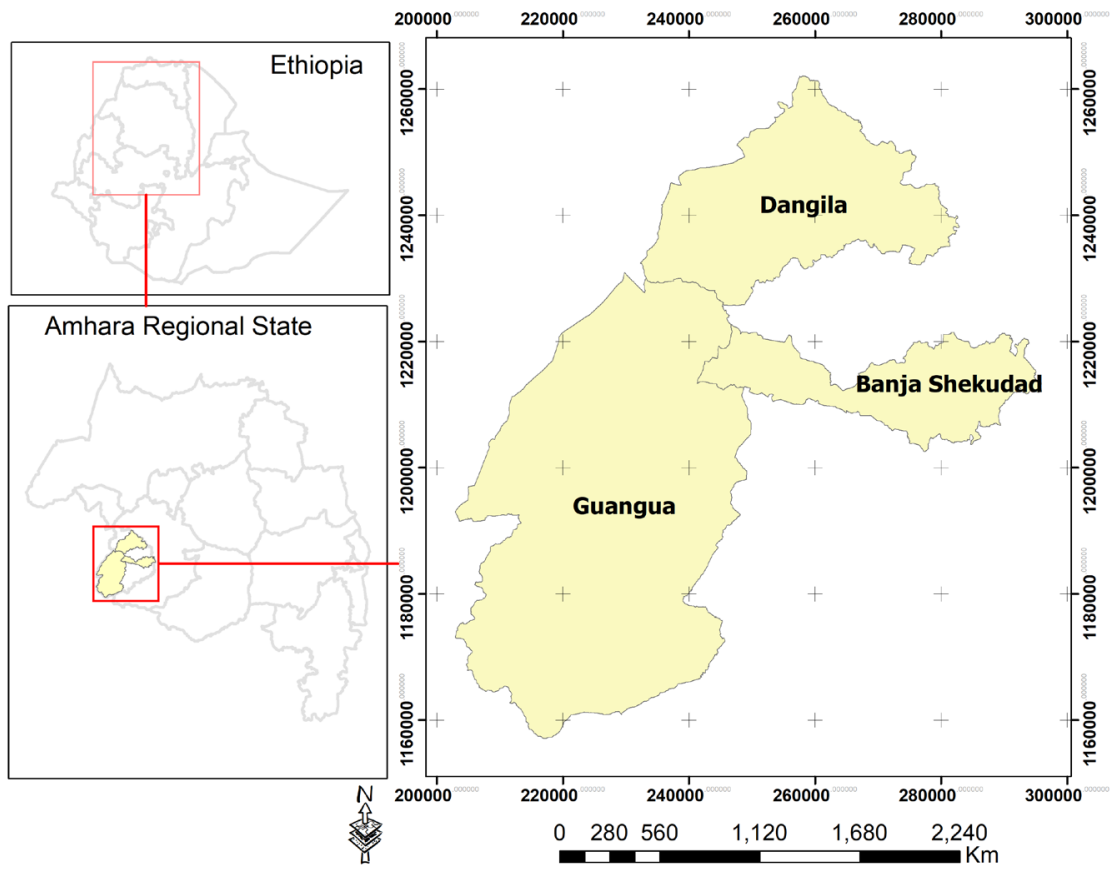

Figure 1. Location map of the study area.

designed, translated to the local language, pretested, and administered. Focus group discussions were held with model farmers and Fogera cattle owners while key informant interviews were held with extension workers, Keble leaders (lower administrative unit), and elderly female and male members of the society. The members of the discussion were known to have a better knowledge of the present and past social and economic status of the area to strengthen the reliability of survey questionnaires. Over 36 years (from 1983 to 2019) climate data of three observatory stations (Chagni, Dangila, and Injibara) were taken from National Meteorological Agency (NMA). The temperature and rainfall data over 36 year's period (1983-2019) were collected to link the trend of climate change with the perception of farmers [25].

\subsection{Sampling Procedure}

The sampling method employed for this study was a multi-stage cluster sampling technique, which was based on the agro-ecological classification of the zone. During this time, a rapid reconnaissance survey was made before the actual survey work to identify the agro-ecological classification. Discussions were held with zonal and district agricultural experts and development agents about agro-ecological classification. Finally, based on their altitude variation districts were clustered into three groups of similar agro-ecological zone as lowland, midland, and highland. According to [18], Awi zone has nine districts and three town administrations from which three districts (Guangua /lowland/, Dangila /midland/, and Banja /highland/) one per cluster were selected randomly. Then, from each district, three kebeles (total of nine kebeles) were selected following 
the same procedure while 150 households having at least three and above Fogera cattle were selected through systematic random sampling based on probability proportionate to the size of the Kebeles' number of households. At this stage, the selection of respondents was made with the local Ministry of Agriculture and Rural Development staffs and Kebele administrators. They have participated in the identification of sampling units and data collection activities.

Sample size for household survey was calculated by the [26] formula;

$$
n=\frac{N}{1+N\left(e^{2}\right)}
$$

where, $N$ is the population size (263) and $e$ is the level of precision (0.05)

\subsection{Method of Data Analysis}

\subsubsection{Perception of Farmers' Analysis}

Pearson Chi-Square $\left(\chi^{2}\right)$ was used to test the association between the farmers' perception and changes in temperature and rainfall patterns [25]. Selected cattle farming attributes were analyzed using Statistical Package for Social Scientists [27]. A one-way analysis of variance was applied for quantitative dependent variables using agro-ecological zone as the independent variable. Tukey Cramer test was used for mean separation for one way analysis of variance. Descriptive statistics, including percentages and frequencies, were applied for summary and presenting the findings. Indices were calculated for perception of farmer's trait preference, and major Fogera cattle production constraints. The following formula was used to compute index as employed by [28]:

$$
\text { Index }=\frac{R_{n} * C_{1}+R_{n-1} * C_{2}+\cdots+R_{1} * C_{n}}{\left(R_{n} * C_{1}+R_{n-1} * C_{2}+\cdots+R_{1} * C_{n}\right)}
$$

where, $R_{n}=$ the last rank (example if the last rank is $8^{\text {th }}$, then

$$
\begin{aligned}
& \left.R_{n}=8, R_{n-1}=7, R_{1}=1\right) . \\
& C_{n}=\text { the number of respondents in the last rank, } \\
& C_{1}=\text { the number of respondents ranked first. }
\end{aligned}
$$

\subsubsection{Rainfall Variability Analysis}

The interannual variability of annual and seasonal precipitation pattern was analyzed as follows:

$$
\mathrm{CV}(\%)=\frac{\sigma}{\mu} \times 100
$$

where, $\mathrm{CV}=$ coefficient of variation $\sigma=$ standard deviation and $\mu=$ mean.

According to [29], the degree of variability of rainfall events can be classified as low $(\mathrm{CV}<20)$, moderate $(20<\mathrm{CV}<30)$, and high $(\mathrm{CV}>30)$.

\subsubsection{Trend Analysis}

Unlike most of the tropics where two seasons are common (wet season and dry season), three seasons are known in Ethiopia, namely Bega (dry season) which ex- 
tends from October-January, Belg (short rainy season) which extends from (February-May), and Kiremt (long rainy season) which extends from June-September [4]. Thus, the study areas were classified as dry season (October-January), short rainy season (February-May) and long rainy seasons (June-September) following [4]. Then the monthly mean rainfall and temperature data were classified and analyzed through the application of descriptive statistics technique that involved the calculation of maximum and minimum of both sets, calculation of annual averages. Trend analysis was conducted using the Mann-Kendall (MK) trend test and Sens's slope estimator [30] [31], as implemented in R-package modifiedmk. The nonparametric Mann-Kendall test (MK) was used for trend analysis as it is widely used to evaluate trends in agro-meteorological and hydrological time series [32] [33] [34]. The strengths of the MK are usually associated with its simple concept and with the fact that as a nonparametric procedure that does not assume a specific joint distribution of the data, it is minimally affected by departures from normality [35]. All-time series data were tested for serial autocorrelation using Durbin-Watson Test in R-car package. Where autocorrelation was not significant, a standard set of tests were applied (command mkktest) while when serial autocorrelation was found to be significant, a trend test was performed following a method proposed by [36] that applies a bias-corrected prewhitening $(b c p w)$ tool found in the same $\mathrm{R}$ package. The rainfall and temperature trends were analyzed using R Software version 3.5.2. The Mann-Kendall test [30] [31] was applied to the long-term data to detect statistically significant trends. In this test, the null hypothesis $\left(\mathrm{H}_{0}\right)$ was that there has been no trend in temperature and precipitation over time; the alternate hypothesis $\left(\mathrm{H}_{1}\right)$ was that there has been a trend (increasing or decreasing) over time.

The Mann-Kendall test [30] [31] was applied using the formula:

$$
S=\sum_{k=1}^{n-1} \sum_{j=i+1}^{n} \operatorname{sgn}\left(x_{j}-x_{k}\right)
$$

where $n=$ number of data points, $x_{k}$ and $x_{j}=$ data values in time series $k$ and $j$ $(j>k)$, and $\operatorname{sgn}\left(x_{j}=x_{k}\right)$ is defined as:

$$
\operatorname{sgn}\left(x_{j}-x_{k}\right)= \begin{cases}+1 & \text { if }\left(x_{j}-x_{k}\right)>0 \\ 0 & \text { if }\left(x_{j}-x_{k}\right)=0 \\ -1 & \text { if }\left(x_{j}-x_{k}\right)<0\end{cases}
$$

The variance of $S$ was calculated as:

$$
\operatorname{VAR}(S)=\left\{\frac{1}{18} n(n-1)(2 n+5)-\sum_{p=1}^{q} t_{p}\left(t_{p}-1\right)\left(2 t_{p}+5\right)\right\}
$$

where $q=$ the number of tied groups and $t_{p}=$ the number of data points in the $p^{\text {th }}$ group.

Whereas the values of $S$ and $\operatorname{VAR}(S)$ are used to compute the test statistic $Z$ as follows: 


$$
Z=\left\{\begin{array}{cc}
\frac{s-1}{\sqrt{V A R(s)}} & \text { for } s>0 \\
0 & \text { for } s=0 \\
\frac{s+1}{\sqrt{V A R(s)}} & \text { for } s<0
\end{array}\right\}
$$

where, the positive values of $Z$ indicate upward (increasing) trends in time series, and the negative values show downward (decreasing) trends. Trends are then tested against some critical values $\left(Z_{1-\alpha}\right)$ to show that either they are statistically significant or not. For example, if $|Z|>Z_{1-\alpha}$ (e.g., $Z_{1-\alpha}$ at $\alpha=0.05$ ); the null hypothesis of no-trend is rejected, and alternative hypothesis of significant trend is accepted.

\subsubsection{Sen's Slope Estimator}

Sen's nonparametric method [31] was used to estimate the magnitude of trends in the time series data as:

$$
\beta=\text { median }\left(\frac{x_{j}-x_{k}}{j-k}\right), j>k
$$

where, $x_{j}$ and $x_{k}$ represent data values at time $j$ and $k$, respectively. $\beta$ is Sen's slope estimate. $\beta>0$ indicates an upward trend in a time series. Otherwise, the data series presents a downward trend during the time period.

\section{Results and Discussions}

\subsection{Livestock Holding}

In all the agro-ecological zones, about $100 \%$ of the interviewed households indicated that livestock keeping and crop production were their major farming activities. Out of the total livestock owned by 150 households, $42.33 \%$ were cattle whereas $32.42 \%, 13.90 \%, 6.73 \%$, and $4.52 \%$ were chicken, sheep, goat, and equines, respectively. The higher proportion of cattle in this area might be attributed to the dominant mixed farming system in the study areas in which cattle are the main source of power for agricultural practices. Moreover, cattle, goat, and chicken holdings were higher in lowland than midland and highland (Table 1). The average numbers of Fogera cattle per household among agro-ecological

Table 1. Livestock holding (mean \pm SE) by different agro-ecological zones per household.

\begin{tabular}{ccccc}
\hline Livestock species & Lowland $(n=58)$ & Midland $(n=49)$ & Highland $(n=43)$ & Overall \\
\hline Cattle & $17.91 \pm 1.21^{\mathrm{a}}$ & $8.16 \pm 1.32^{\mathrm{b}}$ & $14.67 \pm 1.40^{\mathrm{a}}$ & $13.58 \pm 0.76$ \\
Sheep & $3.59 \pm 0.62^{\mathrm{a}}$ & $3.76 \pm 0.68^{\mathrm{a}}$ & $6.02 \pm 0.72^{\mathrm{b}}$ & $4.46 \pm 0.39$ \\
Goat & $4.02 \pm 0.53^{\mathrm{a}}$ & $0.08 \pm 0.57^{\mathrm{b}}$ & $2.37 \pm 0.61^{\mathrm{c}}$ & $2.16 \pm 0.33$ \\
Chicken & $12.10 \pm 1.14^{\mathrm{a}}$ & $10.25 \pm 1.23^{\mathrm{b}}$ & $8.86 \pm 1.32^{\mathrm{b}}$ & $10.40 \pm 0.71$ \\
Horse & $0.05 \pm 0.15^{\mathrm{a}}$ & $0.12 \pm 0.16^{\mathrm{ab}}$ & $0.58 \pm 0.18^{\mathrm{b}}$ & $0.25 \pm 0.097$ \\
Donkey & $1.72 \pm 0.17^{\mathrm{a}}$ & $0.82 \pm 0.18^{\mathrm{b}}$ & $0.52 \pm 0.19^{\mathrm{b}}$ & $1.02 \pm 0.11$ \\
Mule & $0.04 \pm 0.06^{\mathrm{b}}$ & $0.45 \pm 0.06^{\mathrm{a}}$ & $0.07 \pm 0.07^{\mathrm{b}}$ & $0.18 \pm 0.04$
\end{tabular}

Rows with different superscripts are significantly different at $\mathrm{p}<0.05$. 
zones were significantly different. The highest number of cattle per household was recorded in lowland and the lowest one in the midland. Similarly, [37], reported that except for equine, livestock holdings of all types were higher in pastoral/agro-pastoral production systems than lowland crop-livestock systems and highland cereal-livestock systems. The second dominant livestock population in all agro-ecological zones was chicken. The highest mean population was also recorded in the lowland than both midland and highland. This might be because of societies living at lowland economic activities are relatively linked to the livestock rearing as compared to midland and highland farmers whose economic activities principally depend on crop-livestock farming. Goat population was the third reported in the lowland, whereas sheep population was third reported both in midland and highland. This difference might be due to the availability of goat feed resources and the suitability of environmental conditions at lowland than at midland and highland and vis-versa.

\subsection{Perception of Fogera Cattle Farmers on Climate Change and Variability}

The current result revealed that majority (97.13\%) of the farmers perceived that the climate is considerably changing in the area across all the agro-ecological zones. On the other hand, $2.87 \%$ of Fogera cattle owners did not perceive it. About $86.21 \%, 100 \%$, and $90.69 \%$ of the farmers in lowland, midland, and highland, respectively perceived that temperature was noticeably increasing. Moreover, about $72.40 \%, 89.79 \%$, and $83.72 \%$ in lowland, midland, and highland, respectively reported that rainfall was significantly decreasing (Table 2). The

Table 2. Farmers climate change and variability perceptions in percentage at different agro-ecological zones.

\begin{tabular}{|c|c|c|c|c|}
\hline Variables & Lowland $(N=58)$ & Midland $(N=49)$ & Highland $(N=43)$ & $x^{2}$-value \\
\hline \multicolumn{5}{|l|}{ Climate is changing } \\
\hline Yes & 91.38 & 100 & 100 & \\
\hline No & 8.62 & - & - & $8.205^{\star *}$ \\
\hline \multicolumn{5}{|l|}{ Temperature trend } \\
\hline Increased & 86.21 & 100 & 90.69 & \\
\hline Decreased & 13.79 & - & 9.3 & $108.351^{* * *}$ \\
\hline \multicolumn{5}{|l|}{ Rainfall trend } \\
\hline Increased & 27.59 & 10.2 & 16.28 & \\
\hline Decreased & 72.40 & 89.79 & 83.72 & $71.665^{* * * *}$ \\
\hline \multicolumn{5}{|l|}{ Amount of rainfall } \\
\hline Increased & 10.34 & 4.08 & 4.65 & \\
\hline Decreased & 89.65 & 95.91 & 95.35 & $136.435^{* * *}$ \\
\hline \multicolumn{5}{|l|}{ Duration of rainfall } \\
\hline Increased & 22.41 & 20.41 & - & \\
\hline
\end{tabular}




\section{Continued}

\begin{tabular}{ccccc}
\hline Decreased & 77.58 & 79.59 & 100 & $107.010^{* * *}$ \\
Intensity of rainfall & & & & \\
Increased & 32.76 & 14.29 & - & \\
Decreased & 67.24 & 85.71 & 100.00 & $88.905^{* * *}$ \\
* $_{* * *}$ and ${ }^{* *}$ significant at 0.001 , and 0.01 p level, respectively. $N=$ number of respondents, $\chi^{2}$ : chi-square.
\end{tabular}

chi-square test values of survey results show that amount of rainfall, its duration and intensity were significantly declining $(\mathrm{p}<0.001)$ along all the agro-ecological zones. Generally, the majority of households were aware of the occurrence of climate change. They revealed their local experience of climate change incidence using variability in onset and offset time of the rainy season, the decreased number of rainy days, increased drought severity, and the increased number of hot days. Respondents also indicated that short rainy season rainfall is important for the farming community for planting of long rainy season crops like maize and forage. They reported that the short rainy season is becoming irregular, unpredictable, and resulted in frequent Fogera cattle mortality due to a longer dry season, and a significant increase in livestock disease prevalence were happening in the area, as supported by the presented statistical analysis. Similarly, study conducted in the Tigray region of Ethiopia [38], showed that the majority of farmers perceived total rainfall decreased in the last fifteen years in their localities. Another study in northern Tanzania also indicated that farmers were experiencing a reduced amount of rainfall in their respective villages over the last 30 years [39] which is also consistent with this result.

\subsection{Perceived Impact of Climate Change and Variability and Major Adaptation Strategies}

\subsubsection{Impact of Climate Change and Variability}

The majority of Fogera cattle farmers (80.91\%) reported experiencing water shortage as negative impacts of climate change and variability in the study areas. The chi-square test values of survey result indicated that frequency of drought, duration of the dry spell, wind, and floods were significantly increasing ( $\mathrm{p}<$ 0.001 ) in all the agro-ecological zones. Moreover, about $84.48 \%, 65.3 \%$, and $60.47 \%$ of Fogera cattle farmers in the lowland, midland, and highland, respectively perceived that there was significantly an increasing trend of cattle mortality in the study areas $(\mathrm{p}<0.001)$ as shown in Table 3. Moreover, about $55.17 \%$, $61.22 \%$, and $55.81 \%$ of the Fogera cattle owners in lowland, midland, and highland reported that herd size of the Fogera cattle were decreasing in trend whereas $17.24 \%, 30.61 \%$ and $41.86 \%$ reported increasing trend, respectively. However, $27.59 \%, 8.16 \%$, and $2.32 \%$ Fogera cattle owners in lowland, midland, and highland were reported that there was no significant change in cattle numbers due to climate change and variability, respectively over the last 30 years. Livestock production is likely to be adversely affected by climate change, competition 
Table 3. Perceived impact of climate change and variability in percentage at different agro-ecological zones.

\begin{tabular}{|c|c|c|c|c|}
\hline Impact of climate change & Lowland $(N=58)$ & Midland $(N=49)$ & Highland $(N=43)$ & $x^{2}$-value \\
\hline \multicolumn{5}{|l|}{ Water shortage } \\
\hline Yes & 87.93 & 57.14 & 97.67 & \\
\hline No & 12.07 & 42.86 & 2.33 & $73.131^{\star * *}$ \\
\hline \multicolumn{5}{|l|}{ Frequency of drought } \\
\hline Increased & 77.59 & 81.63 & 69.77 & \\
\hline Decreased & 22.41 & 18.37 & 30.23 & $98.946^{* * *}$ \\
\hline \multicolumn{5}{|l|}{ Duration of the dry spell } \\
\hline Increased & 75.86 & 81.63 & 79.01 & \\
\hline Decreased & 24.14 & 20.93 & 20.93 & $109.546^{* * *}$ \\
\hline \multicolumn{5}{|l|}{ Winds and floods } \\
\hline Increased & 70.69 & 59.18 & 90.69 & \\
\hline Decreased & 29.31 & 40.82 & 9.30 & $62.475^{* * *}$ \\
\hline \multicolumn{5}{|l|}{ Forage availability } \\
\hline Increased & 27.59 & 34.69 & 23.26 & \\
\hline Decreased & 72.41 & 65.3 & 76.74 & $5.703^{\mathrm{NS}}$ \\
\hline \multicolumn{5}{|l|}{ Fogera cattle mortality } \\
\hline Increased & 84.48 & 65.3 & 60.47 & \\
\hline Decreased & 15.52 & 34.69 & 39.53 & $46.561^{\star * *}$ \\
\hline \multicolumn{5}{|l|}{ Fogera cattle disease } \\
\hline Increased & 72.41 & 61.22 & 72.09 & \\
\hline Decreased & 27.59 & 38.78 & 27.91 & $1.875^{\mathrm{NS}}$ \\
\hline
\end{tabular}

${ }^{* * *}$ Significant at $\mathrm{p}<0.001$ level while $\mathrm{Ns}=$ non-significant $N$ : number of respondent, $\chi^{2}$ : chi-square.

for land and water, and food security at a time when it is most needed [40]. The most important diseases reported by the Fogera cattle owners were ectoparasites (26.78), foot and mouth diseases (FMD) (15.84), lumpy skin disease (15.84), trypanosomiasis (15.32), endoparasites (13.50), and mastitis (12.72\%). Group discussion with key informants and extension workers with Fogera cattle owners revealed that majority of these diseases have occurred during the short rainy season when there is no adequate feed and water supply. Participants of group discussion also reported that the emergence of new diseases during a severe drought when there was no adequate cattle feed and water sources. These constraints were one of the major problems of communities residing in lowland areas. Previous studies in Ethiopia also reported an increased incidence of diseases during the long dry season [41]. A similar study by [42] reported that FMD, blackleg, and contagious bovine pleuropneumonia (CBPP) were identified as the major diseases of cattle in Borana area. According to [41], decreasing water levels in rivers and low levels of water accumulation in community ponds 
have been observed in recent years in Ethiopia. A study conducted by [43], indicated that the negative impacts of heat stress would become more severe in the future, as a consequence of ever-progressing global warming and genetic selection for higher production continues. The same author also reported that even a minute increase in upper critical temperature might severely hamper the cattle production subjecting the farmers to be highly vulnerable to cope with the challenge. This finding is also in line with review work in India which indicated that climate change negatively impacted cattle production both directly and indirectly [44].

\subsubsection{Major Adaptation Strategies}

The present study revealed three dominant adaptation strategies in the study areas that were reducing the number of livestock, diversification of livestock species, and replacing Fogera cattle with small ruminants. Moreover, mixed farming (crop-livestock), night grazing during hot days, and water harvesting during long rainy season for livestock use were also reported as important adaptation strategies in the study areas (Figure 2). A significant number of Fogera cattle farmers were reported that currently replacing Fogera cattle with small ruminants was becoming an adaptation option because of the shortage of feed resources, especially in the lowland agro-ecological zones. Most of these respondents were reported that they were replacing with small ruminants as small ruminants need relatively small quantities and low-quality feed compared to cattle and equines. Diversification of livestock species is the second important adaptation option reported by the farmers because they believed that if one species fails, they would remain with the other one. In this regard, [17] also reported that due to differences in tolerance to water and feed shortage and resistance to drought among species, multispecies keeping is of vital importance in minimizing

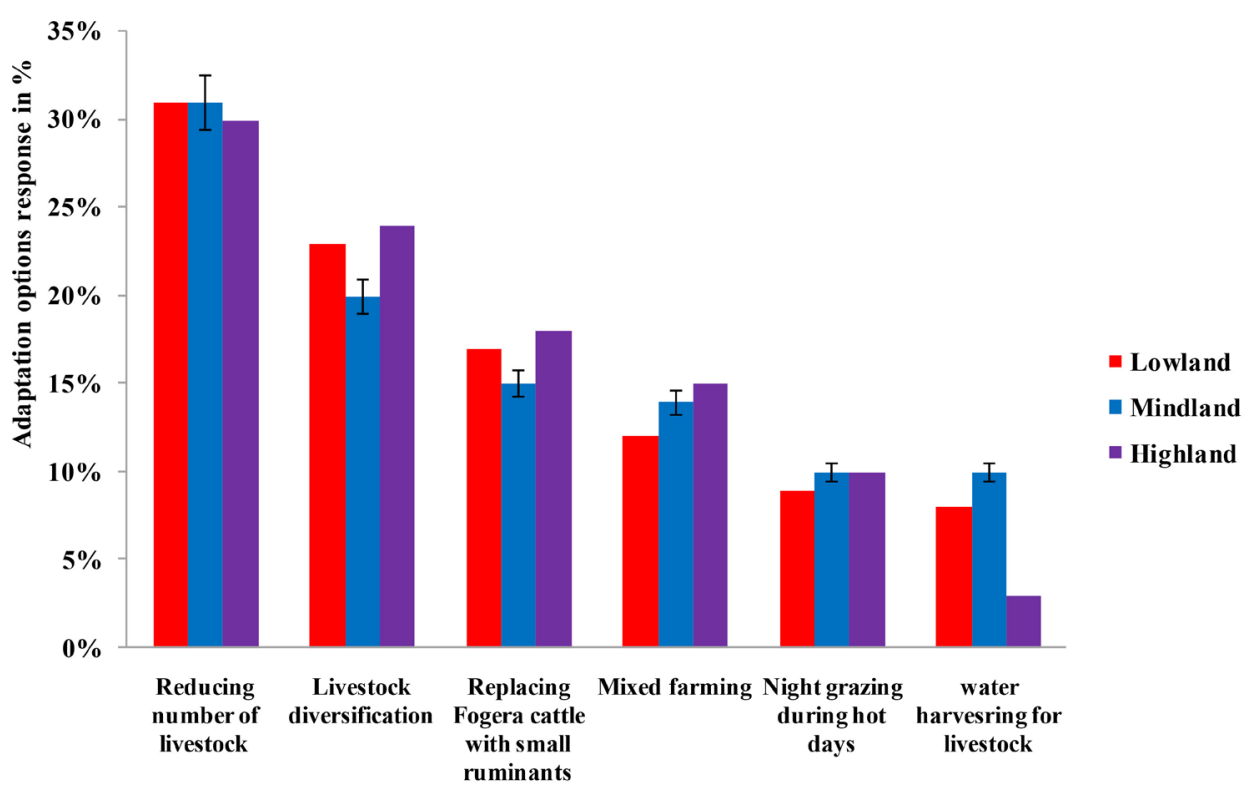

Figure 2. Perceived major adaptation strategies in response to climate change and variability. 
climate-related risks. Similar study in the Borana area reported that recurrent droughts, bush encroachment, increased cattle herd vulnerability, and thus the growing demand for adapted animal species, were the major drivers of livestock diversification [11]. Another study conducted in the Afar region outlined that water harvesting, livestock diversification, cattle restocking, hay production, and purchasing of hay were utilized as among the major adaptation measures [45]. This finding is also in agreement with study conducted in Pakistan which reported that livestock farmers attempted to adopt conventional climate change in their areas using different strategies such as mixed farming, reduction of animals number, provision of more drinking water, use of tree shades, livestock diversification, use of muddy roof, and floor to cope with climate changes [46]. Reducing livestock numbers to match carrying capacity of grazing lands through increased commercial off-take rates and forage development such as elephant grass and fodder trees were potential practices for enhancing the adaptive capacity of communities in pastoral areas [41], which is also consistence with the present result.

\subsection{Major Constraints of Fogera Cattle Farmers at Different Agro-Ecological Zones}

The current result revealed that feed shortage was the dominant constraint with an index value of $0.36,0.35$, and 0.36 in lowland, midland, and highland, respectively (Figure 3). Moreover, the second most important constraint was disease prevalence with an index value of $0.27,0.3$, and 0.32 in lowland, midland, and highland, respectively. A previous study, in the Somali region, indicated that feed constraint was the major and equally important constraint in Gode, Kalafo, and Mustahil in Ogden cattle production with an index value of 0.30 [47]. Fogera cattle owners also reported that feed shortage especially during the dry season (October to January) and short rainy seasons (February to May) were the major

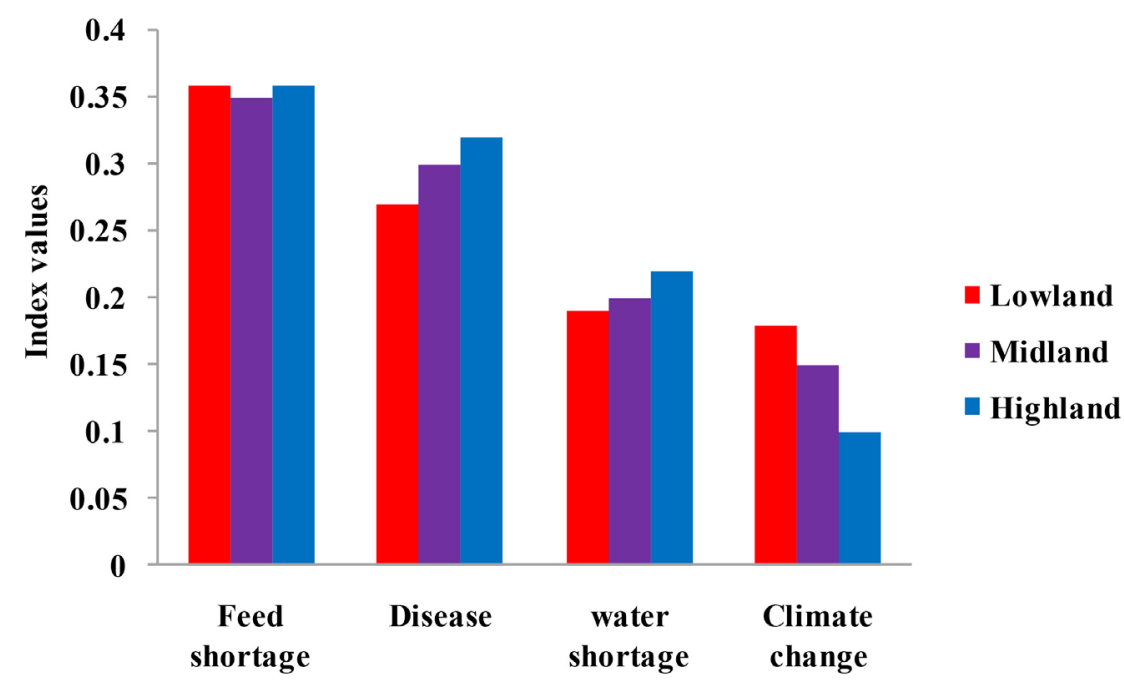

Figure 3. Perceived major constraints of Fogera cattle farmers at different agro-ecological zones. 
constraints in the study areas. In addition to the constraints mentioned above, water shortage followed by climate change was the third and fourth-ranked constraints, respectively. Focus group discussion with model farmers and Fogera cattle owners reported that these constraints were affected cattle production through lengthening age at first service, age at first calving, and calving interval which would increase their cost of production and reduce income that could be expected from cattle production. The present finding corroborates the findings of [48] and [49]. Similarly, a study in West Hararghe Zone of Ethiopia shows that recurrent drought, feed shortage, water scarcity, and feed price increment were among the major constraints of betrothed small-scale cattle fattening business [50].

\subsection{Perceptions of Fogera Cattle Farmers on Trait Preferences}

Milk production was the first preferred trait in selecting females Fogera cattle followed by some adaptive characteristics such as disease-resistant, coat color, appearance, adaptability, and drought tolerance (Figure 4(a)). In the case of males, adaptive characters such as disease-resistant, adaptability, coat color, appearance, and drought tolerance were given priority over milk production (Figure 4(b)). Preferring for better disease resistance in both males and females might suggest the understanding of the farmers on the importance of selecting animals that can withstand disease in the disease-prone areas under the changing environmental condition. A previous study in Kenya shows that milk production, milk fat content, resistance to diseases, low feed requirement, hardship tolerance, and high growth rate of calves in order of importance [51]. Likewise, [47], reported that despite the importance of milk for pastoral and agro-pastoral society, the selection on the male side was less practiced which further confirms the importance of adaptive characters of livestock in pastoral societies which is corroborated with the present findings. Another survey study in the region indicated that there was preference for Fogera cattle over other breeds due to the presence of desired traits in the breed like better milk production, selling price, traction power, adaptability to the local environments, ability to disease resistance, and drought resistance [52], which is in line with the present findings.

\subsection{Trends in Climate Change and Variability}

\subsubsection{Trends of Temperature}

The overall mean annual minimum and maximum temperature in the area range from $11.08^{\circ} \mathrm{C}$ to $26.39^{\circ} \mathrm{C}$, and a higher mean maximum temperature was observed in lowland (Figure 5(a)). Mean annual maximum temperatures ranged from $24.65^{\circ} \mathrm{C}$ to $28.56^{\circ} \mathrm{C}$ and generally higher magnitude was recorded in the short rainy season and lowland agro-ecology. The mean annual minimum temperature ranged from $9.12^{\circ} \mathrm{C}$ to $13.37^{\circ} \mathrm{C}$ (Table 4). The mean annual maximum temperature trend was significantly increasing except for midland. During the short rainy season, it was considerably increasing for all agro-ecological zones. The mean annual maximum temperature trend showed an increasing trend in 


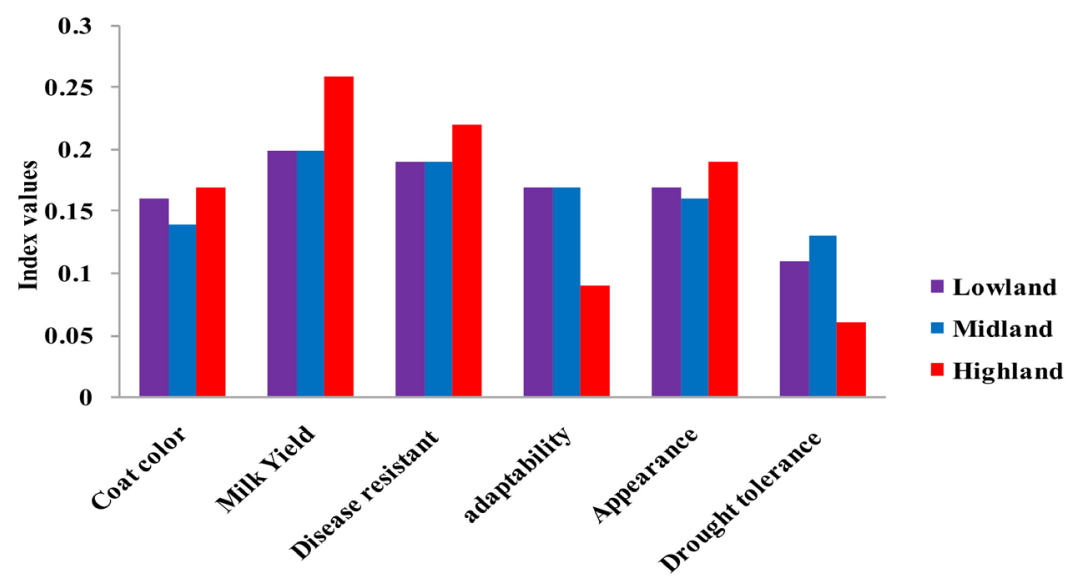

(a)

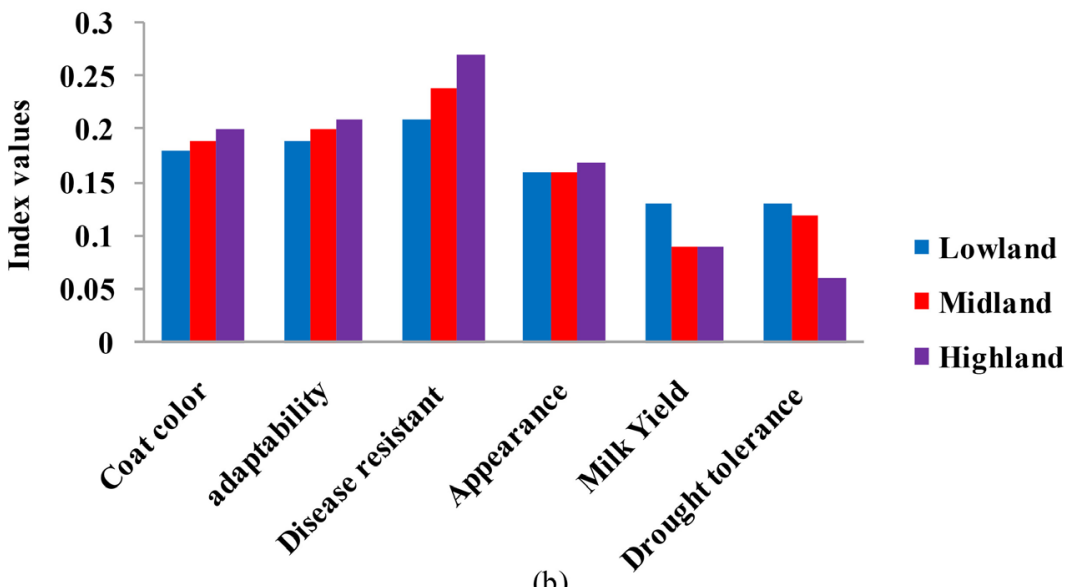

Figure 4. Perception of farmers on trait preferences for female (a) and male (b) Fogera cattle.

Table 4. Mann Kendal (MK) trend analysis of maximum and minim temperature at selected agro-ecological zones (1983-2019).

\begin{tabular}{|c|c|c|c|c|c|c|c|c|c|c|c|c|}
\hline \multicolumn{13}{|c|}{ Maximum Temperature } \\
\hline & \multicolumn{3}{|c|}{ Long rainy season } & \multicolumn{4}{|c|}{ Short rainy season } & \multicolumn{3}{|c|}{ Dry season } & \multicolumn{2}{|c|}{ Annual } \\
\hline Agro & $\mu$ & $Z$ & $\beta$ & $\mu$ & $Z$ & $\beta$ & $\mu$ & $Z$ & $\beta$ & $\mu$ & $Z$ & $\beta$ \\
\hline Lowland & 25.13 & $1.66^{*}$ & 0.02 & 32.07 & $3.22^{\star *}$ & 0.05 & 28.21 & 0.84 & 0.01 & 28.56 & $2.92^{\star *}$ & 0.02 \\
\hline Midland & 23.17 & 0.55 & 0.01 & 28.83 & $2.40^{*}$ & 0.04 & 26.86 & 0.70 & 0.01 & 25.95 & 1.64 & 0.01 \\
\hline Highland & 22.26 & 1.55 & 0.01 & 26.74 & $2.55^{\star \star}$ & 0.04 & 24.96 & 1.56 & 0.02 & 24.65 & $4.41^{\star *}$ & 0.02 \\
\hline \multicolumn{13}{|c|}{ Minimum Temperature } \\
\hline & \multicolumn{3}{|c|}{ Long rainy season } & \multicolumn{4}{|c|}{ Short rainy season } & \multicolumn{3}{|c|}{ Dry season } & \multicolumn{2}{|c|}{ Annual } \\
\hline Agro & $\mu$ & $Z$ & $\beta$ & $\mu$ & $Z$ & $\beta$ & $\mu$ & $Z$ & $\beta$ & $\mu$ & $Z$ & $\beta$ \\
\hline Lowland & 15.06 & $4.83^{\star * *}$ & 0.04 & 13.89 & $4.02^{* * *}$ & 0.06 & 11.18 & $4.46^{* * *}$ & 0.06 & 13.37 & $5.14^{\star * *}$ & 0.04 \\
\hline Midland & 12.51 & $3.68^{\star * *}$ & 0.04 & 11.08 & $3.29^{\star * *}$ & 0.05 & 8.65 & $4.13^{* * *}$ & 0.06 & 10.75 & $4.64^{\star * *}$ & 0.04 \\
\hline Highland & 8.00 & $2.56^{\star *}$ & 0.01 & 10.8 & $2.16^{\star *}$ & 0.02 & 8.50 & $1.67^{\star}$ & 0.01 & 9.12 & $2.58^{\star *}$ & 0.01 \\
\hline
\end{tabular}




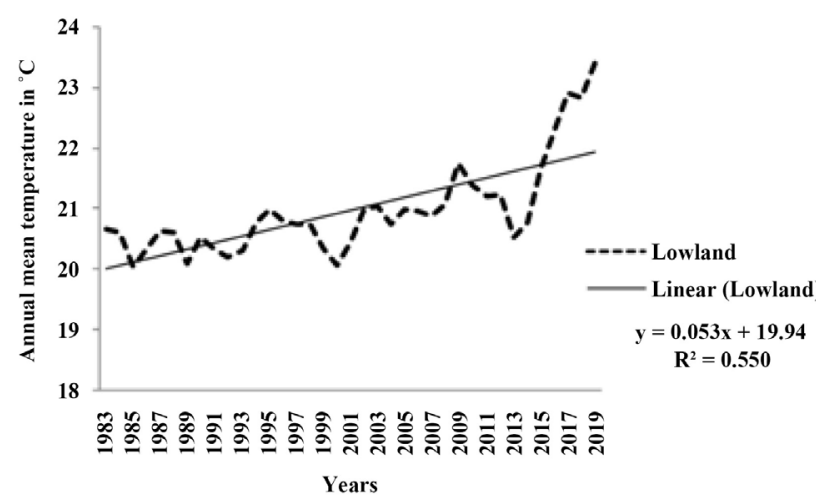

(a)

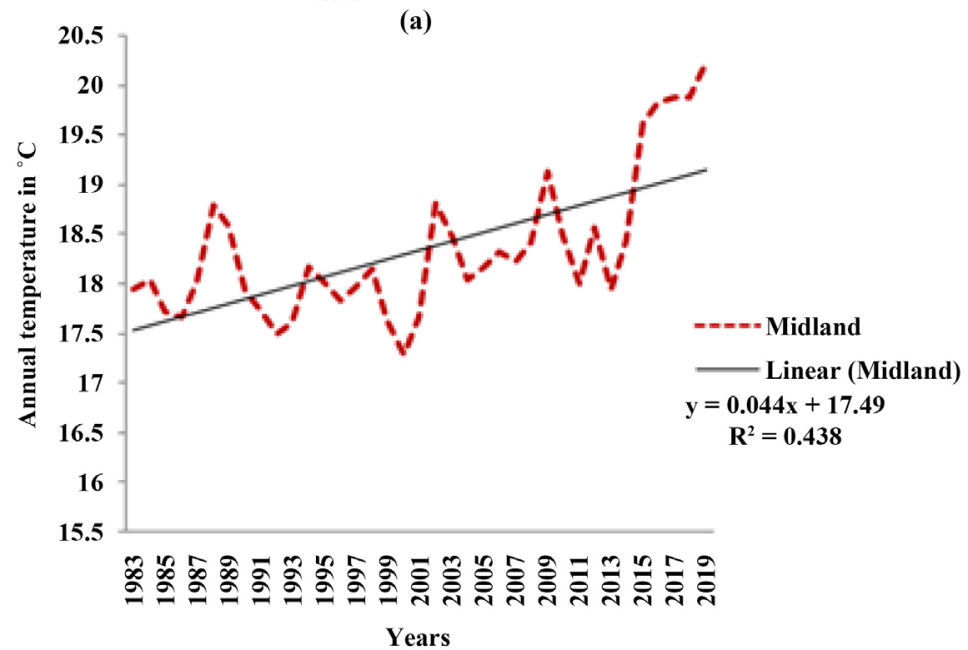

(b)

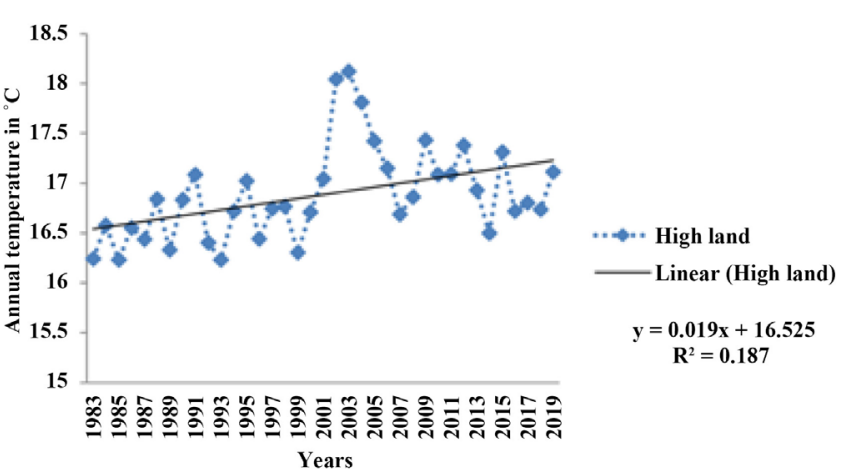

(c)

Figure 5. Annual mean temperature trend at lowland (a), midland (b), and highland (c) agro-ecological zones in the study areas.

the study areas which will help the planners to design appropriate strategies to minimize the impact of temperature on the livelihood of the farmers. Moreover, the mean annual minimum temperature trend was significantly increasing for all the agro-ecological zones. The mean minimum temperature trend was also significantly increasing during the long rainy season, short rainy season, and dry season along all agro-ecological zones considered. The mean annual temperature was significantly increasing for all agro-ecological zones as shown in Figures 5(a)-(c), which supports the statistical result. Farmers, key informants, and extension workers participated in the focus group discussion and interview also explained that temperature was increasing every year, which also confirms the statistical results. Another study conducted in the area also showed that most residents perceived that temperature had been increasing while rainfall was declining over the last decades [12] and [13] which were also consistent with the current findings. Most of the previous studies in this region [53] [54] [55] and in Ethiopia in general [14] also confirmed the presence of significant increasing trends in temperature.

\subsubsection{Trends of Rainfall}

The current result revealed that the mean annual rainfall ranges from 1130 to 


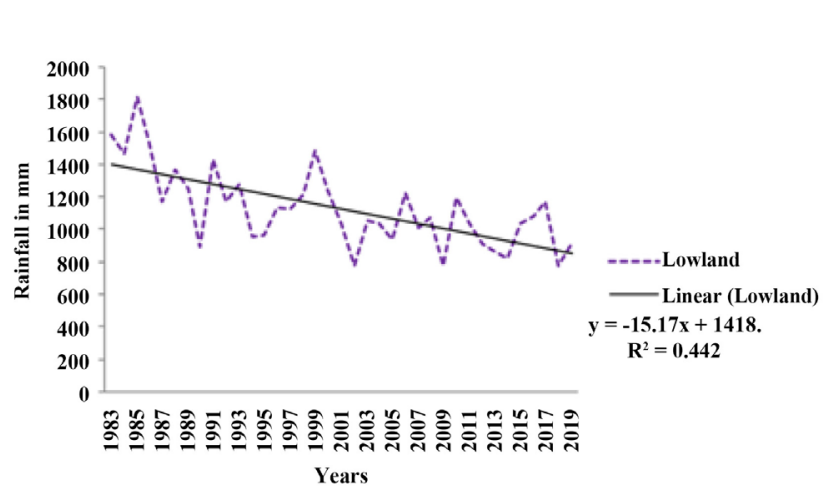

(a)

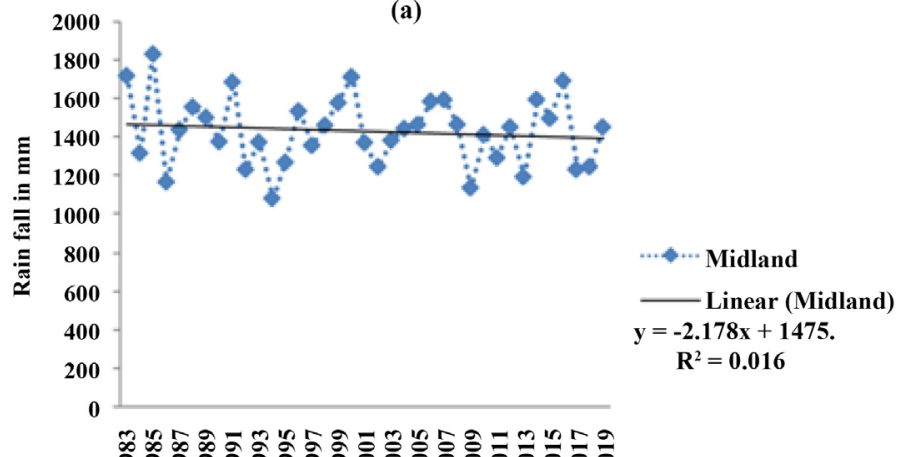

Years

(b)
$1602 \mathrm{~mm}$ and a higher mean rainfall was observed in highland during long rainy season (Table 5). The mean annual rainfall trend was significantly decreasing in the lowland agro-ecological zone. Moreover, the mean annual rainfall trend was also decreasing in all agro-ecological zones although the level of decreasing trend was varied (Figures 6(a)-(c)). The MK test also shows that the mean annual rainfall was decreasing in midland and highland nevertheless the trend was not significant (Table 5). The long rainy season mean rainfall trend was decreasing significantly in lowland and highland agro-ecological zones. Even though the trend of long rainy season shows decreasing in midland agro-ecological zone but it was not significant (Table 5). Furthermore, the short rainy season mean rainfall trend was also indicated that decreasing in all agro-ecological zones but the

Table 5. Mann Kendal (MK) trend analysis of rainfall at selected agro-ecological zones (1983-2019).

\begin{tabular}{ccccccccccccccc}
\hline & \multicolumn{2}{c}{ Long rain season } & \multicolumn{2}{c}{ Short rain season } & \multicolumn{3}{c}{ Dry season } & \multicolumn{3}{c}{ Annual } \\
\hline Agro & $\mu$ & $\mathrm{Z}$ & $\beta$ & $\mu$ & $\mathrm{Z}$ & $\beta$ & $\mu$ & $\mathrm{Z}$ & $\beta$ & $\mu$ & $\mathrm{Z}$ & $\beta$ \\
\hline Lowland & 889 & $-3.39^{* * *}$ & -11.59 & 141 & -0.77 & -1.35 & 99 & -1.03 & -0.79 & 1130 & $-4.06^{* * *}$ & -1.48 \\
Midland & 1157 & -0.82 & -1 & 162 & -0.17 & -0.25 & 115 & 0.9 & 0.91 & 1434 & -0.3 & -1 \\
Highland & 1315 & $-1.82^{*}$ & -4.79 & 167 & -0.41 & -0.73 & 118 & 6.41 & 0.6 & 1602 & -1.4 & -5.4 \\
\hline
\end{tabular}

NB: Agro $=$ Agro-ecological zones, $\mu=$ Mean, $\beta=$ Sen's Slope, $Z=$ Mann Kendal test, $\mu=$ Mean, ${ }^{\star}$ and ${ }^{* * *}$ is significant at 0.05 , and 0.001 while ns $=$ non-significant at $\mathrm{p}<0.05$.

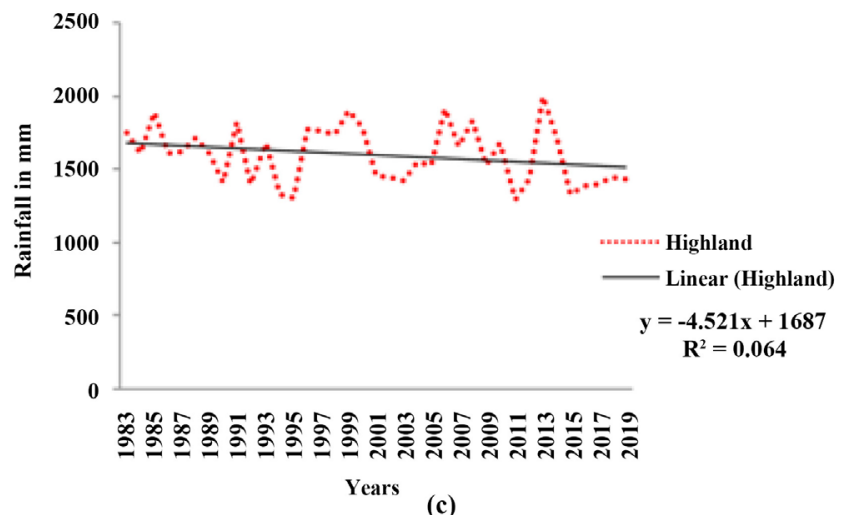

(c)

Figure 6. Annual mean rainfall trend in lowland (a), midland (b), and highland (c) agro-ecological zones in the study areas. 
trend was not significant. The dry season mean rainfall showed that decreasing in lowland while increasing in midland and highland however the trend was not significant in all agro-ecological zones. The majority of the farmers, key informants, and extension workers participated in the focus group discussion and interview also indicated that rainfall had been decreasing every year. About $56.89 \%, 89.79 \%$, and $83.72 \%$ of the respondents reported that rainfall was decreasing year after year in lowland, midland, and highland agro-ecological zones, respectively that are in line with the statistical results. The amount, duration, and intensity of rainfall were also decreasing in the study areas. Another survey research result in the area also reported that farmers perceived that the rise of temperature and a decline of rainfall [12], which is also in agreement with the current findings. Study in Pakistan also showed that summer season experienced significant negative trends [56].

\subsubsection{Variability of Rainfall}

The annual rainfall pattern in the area is dominated by the long rainy season. Due to this reason, annual rainfall and long rainy season rainfall showed similar coefficient of variation (CV) across all agro-ecological zones (Figure 7(a), and Figure $7(\mathrm{~b})$ ). As rainfall is comparatively abundant in the long rainy season that contributes $(80.68 \%)$ in the study area, the CV is generally lowest along all

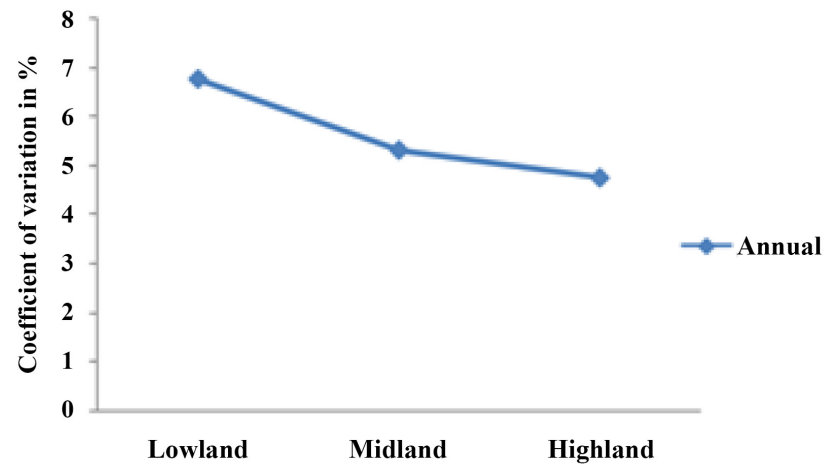

(a)

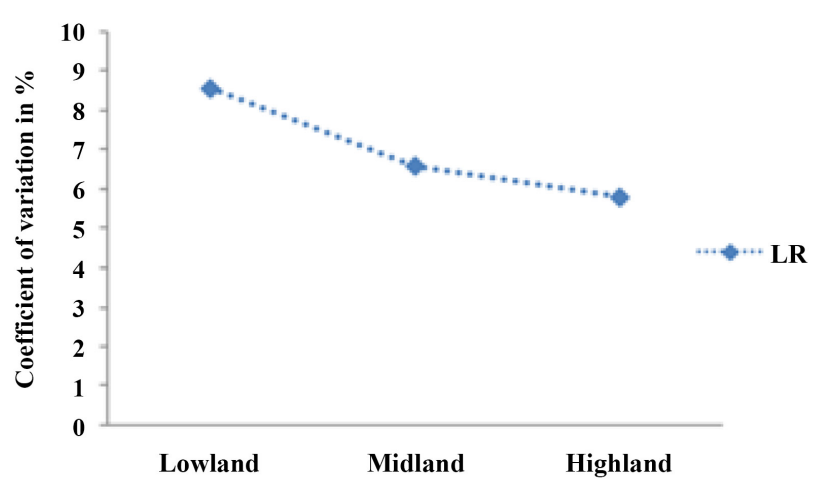

(b)

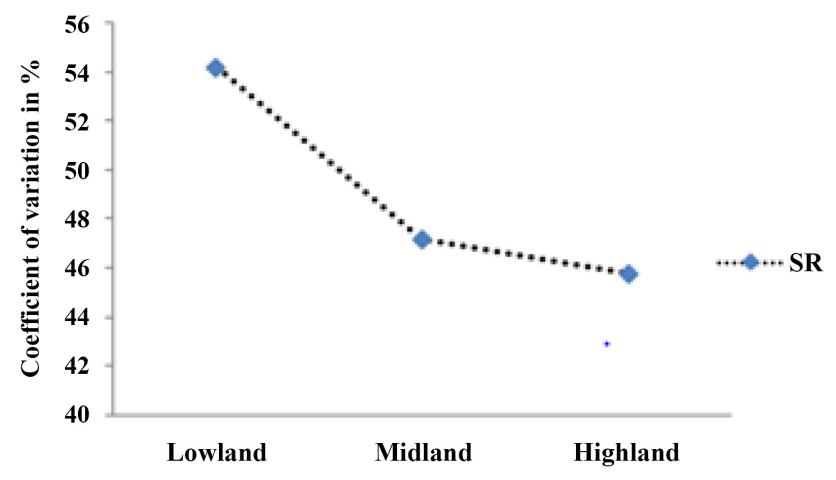

(c)

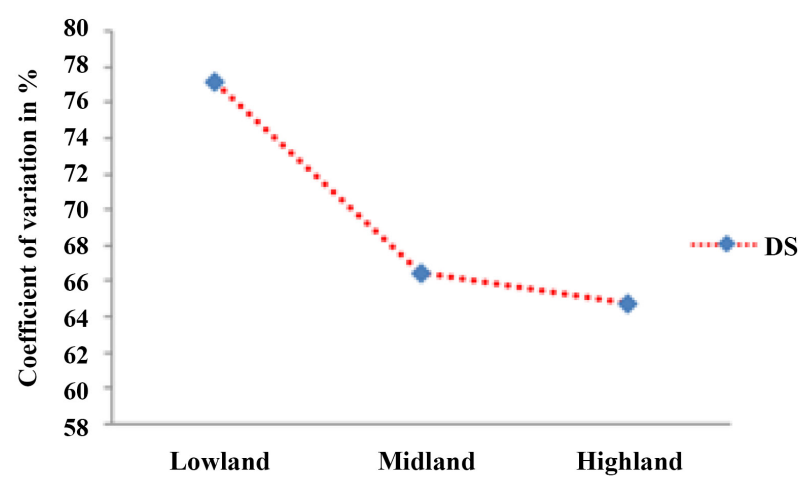

(d)

Figure 7. Coefficient of variation in percentage in agro-ecological zones (1983-2019). Where, LR = Long rainy season, SR = Short rainy season, and DS = Dry season. 
agro-ecological zones. The CV falls below $20 \%$ in all cases for both annual and long rainy season. Moreover, $\mathrm{CV}$ was the smallest in the highland agro-ecological zone, where mean rainfall was the greatest. The short rainy season which contributes (11.28\%) and dry season which contributes (7.97\%) had considerably lower total rainfall than the long rainy season and showed high interannual variability at all along all agro-ecological zones (Figure $7(\mathrm{c})$, and Figure $7(\mathrm{~d})$ ). Even though the highland agro-ecological zone tends to show a slightly smaller CV than the lowland agroecology, it had CV greater than $45 \%$ in the short rainy season and greater than $64 \%$ in the dry season. The current result is in line with the findings of [15]. Similar study conducted in the region also reported Ethiopian rainfall is highly variable [14].

\section{Conclusion}

The current result revealed that climate is variable in the study area. Meteorological result indicated that the annual mean temperature was increasing, while rainfall was decreasing. The short rainy season and dry season rainfall showed high interannual variability at all agro-ecological zones. Farmers' perceptions were in agreement with meteorological results. Farmers also indicated that forage and water availabilities were decreasing from time to time. However, drought frequency, Fogera cattle diseases, and mortality were increasing. To reduce the adverse effect of climate change farmers have developed their adaptation strategies. Relatively farmers preferred better disease resistance trait as adaptive characters in both male and female animals. Thus, future research efforts should be geared towards improving these traits. Fogera cattle owners also reported that the number of this breed was declining over time. Therefore, future research both on station and at farm level should be geared towards conservation strategies of the breed. A breeding strategy that should take into account disease resistance and adaptation traits should be considered in the future. Regular prediction of climate change and variability and designing pertinent response strategies is essential to reduce the adverse impacts of climate change for enhancing resilience capacity of Fogera cattle farmers in the study areas.

\section{Limitation of the Study}

This study was mainly targeted at Fogera cattle owners. Thus, further research is needed to understand how other livestock owners perceive climate change and variability and respond to perceived changes.

\section{Acknowledgements}

The authors are grateful to the Africa Centre of Excellence for Climate Smart and Biodiversity Conservation for sponsoring this research as part of PhD study. We would also like to acknowledge Debre Markos University and the Ministry 
of Education for their support to undertake this study. National Meteorological Agency, Agricultural Bureau Experts are also acknowledged for providing climate data, and facilitation of the interview, respectively. The development agents and farmers who participated in the interview are highly appreciated and acknowledged.

\section{Conflicts of Interest}

The authors declare no conflicts of interest regarding the publication of this paper.

\section{References}

[1] Funk, C., Rowland, J., Eilerts, G., Emebet, K., Nigist B., White, L. and Galu, G. (2012) A Climate Trend Analysis of Ethiopia. US Geological Survey, Fact Sheet, 5, 6. https://doi.org/10.3133/fs20123053

[2] CSA (2018) Central Statistical Agency Agricultural Sample Survey. Livestock and Livestock Characteristics.

[3] National Meteorological Services Agency (NMSA) (2001) Initial National Communication of Ethiopia to the United Nations Framework Convention on Climate Change (UNFCCC). Addis Ababa.

[4] National Meteorological Agency (NMA) (2007) Climate Change National Adaptation Program of Action of Ethiopia. Addis Ababa.

[5] Alebachew, A. and Woldeamlak, B. (2011) A Climate Change Country Assessment Report for Ethiopia. Submitted to Forum for Environment. Epsilon International $\mathrm{R} \& \mathrm{D}$, Addis Ababa.

[6] World Bank (2010) The Social Dimensions of Adaptation to Climate Change in Ethiopia. Development and Climate Change Discussion Papers No. 14. Washington DC.

[7] Intergovernmental Panel on Climate Change (IPCC) (2007) Climate Change 2007: Impacts, Adaptation, and Vulnerability. Summary for Policymakers.

http://www.ipcc.cg/SPM13apr07.pdf

[8] IFAD (2009) Livestock and Climate Change. Livestock Thematic Papers Tools for Project Design. International Fund for Agricultural Development, Rome.

[9] Intergovernmental Panel on Climate Change (IPCC) (2014) Climate Change 2014: Impacts, Adaptation, and Vulnerability. Fifth Assessment Report.

https://doi.org/10.1017/CBO9781107415416

[10] Garnett, T. (2009) Livestock-Related Greenhouse Gas Emissions: Impacts and Options for Policymakers. Environmental Science \& Policy, 12, 491-503. https://doi.org/10.1016/j.envsci.2009.01.006

[11] Bekele, B. (2013) Climate Change, Cattle Herd Vulnerability, and Food Insecurity: Adaptation through Livestock Diversification in the Borana Pastoral System of Ethiopia. Doctoral Dissertation, Kommunikations-, Informations-und Medienzentrum der Universität Hohenheim.

[12] Abebaw, A. (2016) Smallholder Farmer's Perception to Climate Change: The Case of AnkeshaGuagusa District of Awi Zone, Northwestern Ethiopia.

[13] Weldlul, L. (2016) Analysis of Smallholder Farmers' Perceptions of Climate Change and Adaptation Strategies to Climate Change: The Case of Western Amhara Region, 
Ethiopia. Ethiopia Doctoral Thesis University of South Africa.

[14] Addisu, S., Selassie, Y.G., Fissha, G. and Gedif, B. (2015) Time Series Trend Analysis of Temperature and Rainfall in Lake Tana Sub-Basin, Ethiopia. Environmental Systems Research, 4, 25. https://doi.org/10.1186/s40068-015-0051-0

[15] Dereje, A., Benjamin, F., Kindie, T., Belay, S., Getachew, A. and Enyew, A. (2020) Climate Trends and Variability at Adaptation Scale: Patterns and Perceptions in an Agricultural Region of the Ethiopian Highlands. Weather and Climate Extremes, 29, Article ID: 100263. https://doi.org/10.1016/j.wace.2020.100263

[16] Endalkachew, N., Solomon, A. and Firew, T. (2020) Livestock Diversification Prospects for Climate Change Adaptation in Dangila District, Ethiopia. Tropical Animal Health and Production, 52, 1435-1446.

[17] Bekele, M., André, M., Ayana, A. and Anne, V. (2014) The Role of Livestock Diversification in Ensuring Household Food Security under a Changing Climate in Borana, Ethiopia. Food Security, 6, 15-28. https://doi.org/10.1007/s12571-013-0314-4

[18] Awi Zone Agricultural and Rural Development Office (AZARDO) (2019) Awi Zone Annual Report, Injibara, Ethiopia.

[19] Yaregal, M., Ayana, A. and Aster, A. (2019) Effects of Grazing Intensity to Water Source on Grassland Condition, Yield and Nutritional Content of Selected Grass Species in Northwest Ethiopia.

[20] Melak, Y. (2017) Effects of Distance from Water Points on Grassland Condition, Biomass Production, and Nutritional Quality of Grasses in Chagni Ranch, North West Ethiopia. MSc. Thesis, Hawassa University, Hawassa.

[21] Genet, E., Abeje, G. and Ejigu, T. (2015) Determinants of Unmet Need for Family Planning among Currently Married Women in Dangila Town Administration, Awi Zone, Amhara Regional State; a Cross-Sectional Study. Reproductive Health, 12, 42. https://doi.org/10.1186/s12978-015-0038-3

[22] Abera, B. and Kibret, M. (2014) Azithromycin, Fluoroquinolone and Chloramphenicol Resistance of Non-Chlamydia Conjunctival Bacteria in Rural Community of Ethiopia. Indian Journal of Ophthalmology, 62, 236. https://doi.org/10.4103/0301-4738.99974

[23] Leyew, Z. (2011) Wild Plant Nomenclature and Traditional Botanical Knowledge among Three Ethnolinguistic Groups in Northwestern Ethiopia. African Books Collective.

[24] Fentahun, A., Yehualashet, B., Alemayehu, K. and Teshome, S. (2017) Carbon Stock of Banja Forest in Banja District, Amhara Region, Ethiopia: An Implication for Climate Change Mitigation. Journal of Sustainable Forestry, 36, 604-622. https://doi.org/10.1080/10549811.2017.1332646

[25] Innocent, N., Michael, K., Daniel, M., Cecilia, G. and Joseph, K. (2016) The Trend of Climate Variability Effects on Dairy Farming in Masaba North, Nyamira County Kenya. Journal of Environment and Earth Science, 6, 129.

[26] Yamane, T. (1967) Research Methods: Determination of Sample Size.

[27] IBM Corp (2016) Ibm SPSS Statistics: Version 23.0.

[28] Musa, L.M.-A., Peters, K.J. and Ahmed, M.-K.A. (2006) On-Farm Characterization of Butana and Kenana Cattle Breed Production Systems in Sudan. Livestock Research for Rural Development, 18, 177.

[29] Hare, W. (2003) Assessment of Knowledge on Impacts of Climate Change-Contribution to the Specification of Art. 2 of the UNFCCC: Impacts on Ecosystems, Food Produc- 
tion, Water, and Socio-Economic Systems.

[30] Mann, H.B. (1945) Nonparametric Tests against Trend. Econometrica: Journal of the Econometric Society, 13, 245-259. https://doi.org/10.2307/1907187

[31] Sen, P.K. (1968) Estimates of the Regression Coefficient Based on Kendall's Tau. Journal of the American Statistical Association, 63, 1379-1389.

https://doi.org/10.1080/01621459.1968.10480934

[32] Blain, G.C. (2010) Séries anuais de temperatura máxima média do ar no Estado de São Paulo: Variações e tendências climáticas. Revista Brasileira de Meteorologia, 25, 114-124. https://doi.org/10.1590/S0102-77862010000100010

[33] Blain, G.C. and Pires, R.C.D.M. (2011) Variabilidade temporal da evapotranspiração real e da razão entre evapotranspiração real e potencial em Campinas, Estado de São Paulo. Bragantia, 70, 460-470. https://doi.org/10.1590/S0006-87052011000200030

[34] Minuzzi, R.B., Caramori, P.H. and Borrozino, E. (2011) Tendências na variabilidade climática sazonal e anual das temperaturas máxima e mínima do ar no Estado do Paraná. Bragantia, 70, 471-479. https://doi.org/10.1590/S0006-87052011000200031

[35] Yue, S. and Pilon, P. (2004) A Comparison of the Power of the Test, Mann-Kendall and Bootstrap Tests for Trend Detection/Une comparaison de la puissance des tests t de Student, de Mann-Kendall et du bootstrap pour la détection de tendance. $H y$ drological Sciences Journal, 49, 21-37. https://doi.org/10.1623/hysj.49.1.21.53996

[36] Hamed, K.H. (2009) Enhancing the Effectiveness of Prewhitening in Trend Analysis of Hydrologic Data. Journal of Hydrology, 368, 143-155.

https://doi.org/10.1016/j.jhydrol.2009.01.040

[37] Dereje, T., Mengistu, U., Getachew, A. and Yoseph, M. (2014) Perceptions of Households on the Purpose of Keeping, Trait Preference, and Production Constraints for Selected Goat Types in Ethiopia. Tropical Animal Health and Production, 46, 363-370. https://doi.org/10.1007/s11250-013-0497-x

[38] Hailey, K., Dawit, D., Belay Simane, B. and Tagel, G. (2019) Farmers' Perceptions of Climate Change Trends and Adaptation Strategies in Semiarid Highlands of Eastern Tigray, Northern Ethiopia. Advances in Meteorology, 2019, Article ID: 3849210. https://doi.org/10.1155/2019/3849210

[39] Esther, G., Siobhan, M. and Jenny-Ann, L.M.L. (2018) Climate Change Perception and Impacts on Cattle Production in Pastoral Communities of Northern Tanzania. Pastoralism, 8, 19. https://doi.org/10.1186/s13570-018-0125-5

[40] Thornton, P.K. (2010) Livestock Production: Recent Trends, Future Prospects. Philosophical Transactions of the Royal Society B: Biological Sciences, 365, 2853-2867. https://doi.org/10.1098/rstb.2010.0134

[41] Woldeamlak, B., Maren, A. and Mungai, C. (2015) Agricultural Adaptation and Institutional Responses to Climate Change Vulnerability in Ethiopia.

[42] Zelalem, Y., Aynalem, H., Emmanuelle, G. and Addis, A. (2009) Effect of Climate Change on Livestock Production and Livelihood of Pastoralists in Selected Pastoral Areas of Borana, Ethiopia. ESAP Proceedings, Addis Ababa, 24-26 September 2009, 3-21.

[43] Wheelock, J.B., Rhoads, R.P., VanBaale, M.J., Sanders, S.R. and Baumgard, L.H. (2010) Effects of Heat Stress on Energetic Metabolism in Lactating Holstein Cows. Journal of Dairy Science, 93, 644-655. https://doi.org/10.3168/jds.2009-2295

[44] Angel, S.P., Amitha, J.P., Rashamol, V.P., Vandana, G.D., Savitha, S.T., Afsal, A., 
Bagath, M., Krishnan, G. and Sejian, V. (2018) Climate Change and Cattle Production-Impact and Adaptation. Journal of Veterinary Medicine Research, 5, 1134.

[45] Melaku, B., Dana, H., Girmay, T., Shunji, O. and Masaru, K. (2016) Effects of Adaptation to Climate Change on an Income of Cattle Owners in the Pastoral and Agro-Pastoral Communities of Northern Ethiopia.

[46] Shahbaz, P., Boz, I. and ul Haq, S. (2020) Adaptation Options for Small Livestock Farmers Having Large Ruminants (Cattle and Buffalo) against Climate Change in Central Punjab Pakistan. Environmental Science and Pollution Research, 27, 17935-17948. https://doi.org/10.1007/s11356-020-08112-9

[47] Mummed, Y.Y. (2019) Traditional Selection Criteria of Ogaden Cattle in Pastoral and Agro Pastoral Production Systems and Its Implication to Resilience of the Breed in the Face of Climate Change in the Future. Open Journal of Animal Sciences, 9, 355-366. https://doi.org/10.4236/ojas.2019.93029

[48] Bezahegn, A. and Mengistu, U. (2014) Small Scale Beef Cattle Fattening Practices, On-Farm Performance Evaluation, and Opportunities for Market Orientation in Western Hararghe Zone Chiro District. M.Sc. Thesis, Haramaya University, Haramaya.

[49] Dadi, G., Urge, M. and Teklebrhan, T. (2017) Assessment of Commercial Beef Cattle Fattening Practices and Performance in East Shoa Zone. International Journal of Agricultural Science and Food Technology, 3, 67-76. https://doi.org/10.17352/2455-815X.000025

[50] Adunea, D. (2019) Assessment of Constraints and Opportunities in Small-Scale Beef Cattle Fattening Business: Evidence from the West Hararghe Zone of Ethiopia. International Journal of Veterinary Science Research, 5, 58-68. https://doi.org/10.17352/ijvsr.000042

[51] Lukuyu, M.N., Gibson, J.P., Savage, D.B., Rao, E.J.O., Ndiwa, N. and Duncan, A.J. (2019) Farmers' Perceptions of Dairy Cattle Breeds, Breeding, and Feeding Strategies: A Case of Smallholder Dairy Farmers in Western Kenya. East African Agricultural and Forestry Journal, 83, 351-367. https://doi.org/10.1080/00128325.2019.1659215

[52] Assemu, T., Dilip, K., Solomon, A. and Getinet, M. (2017) Conservation and Improvement Strategy for Fogera Cattle: A Lesson for Ethiopia Ingenious Cattle Breed Resource. Advances in Agriculture, 2017, Article ID: 2149452.

https://doi.org/10.1155/2017/2149452

[53] Mengistu, D., Bewket, W. and Lal, R. (2014). Recent Spatiotemporal Temperature and Rainfall Variability and Trends over the Upper Blue Nile River Basin, Ethiopia. International Journal of Climatology, 34, 2278-2292.

https://doi.org/10.1002/joc.3837

[54] Alemayehu, A. and Bewket, W. (2017) Smallholder Farmers' Coping and Adaptation Strategies to Climate Change and Variability in the Central Highlands of Ethiopia. Local Environment, 22, 825-839. https://doi.org/10.1080/13549839.2017.1290058

[55] Asfaw, A., Simane, B., Hassen, A. and Bantider, A. (2018) Variability and Time Series Trend Analysis of Rainfall and Temperature in Northcentral Ethiopia: A Case Study in Woleka Sub-Basin. Weather and Climate Extremes, 19, 29-41.

https://doi.org/10.1016/j.wace.2017.12.002

[56] Ahmad, I., Tang, D., Wang, T., Wang, M. and Wagan, B. (2015) Precipitation 
Trends over Time Using Mann-Kendall and Spearman's Rho Tests in Swat River Basin, Pakistan. Advances in Meteorology, 2015, Article ID: 431860.

https://doi.org/10.1155/2015/431860 